\title{
Arsenic, chromium, copper, iron, manganese, lead, selenium and zinc in the tissues of the largemouth yellowfish, Labeobarbus kimberleyensis (Gilchrist and Thompson, 1913), from the Vaal Dam, South Africa, and associated consumption risks
}

\author{
BM Gilbert ${ }^{1}$ and A Avenant-Oldewage ${ }^{1 *}$ \\ 'Department of Zoology, University of Johannesburg, PO Box 524, Auckland Park, 2006, Johannesburg, South Africa
}

\begin{abstract}
This paper addresses the accumulation of trace elements in the water, sediment and tissues of Labeobarbus kimberleyensis from the Vaal Dam, South Africa. Fish were collected from the Vaal Dam during February to April 2011. Five organs, water and sediment were collected and trace element concentrations were measured with an ICP-MS. Target hazard quotients were calculated to assess the human health risk associated with consuming muscle tissue of this fish species. Trace element levels for $\mathrm{Cu}, \mathrm{Fe}$ and $\mathrm{Mn}$ were higher in water and sediment compared to L. kimberleyensis. Sediment element levels were highest compared to water and fish. Clear trends in element accumulation by the different organs were observed. Liver and kidney accumulated the highest element concentrations, followed by the gills, muscle and spinal cord. Bioconcentration factors further supported the observation that trace element accumulation was lower in fish compared to sediment. The high sediment element levels indicate that there is a low bioavailability of elements for accumulation by biota in the Vaal Dam. Target hazard quotient determination indicated that risk associated with the consumption of muscle tissue from L. kimberleyensis was low for most elements, except $\mathrm{Cr}$ and Se. Element levels in L. kimberleyensis, water and sediment have increased compared to previous studies on the Vaal Dam.
\end{abstract}

Keywords: bioaccumulation; Labeobarbus kimberleyensis; risk assessment; target hazard quotient; trace element; Vaal Dam; water quality

\section{INTRODUCTION}

Globally, trace element levels in ecosystems have increased as a result of anthropogenic activities. Aquatic ecosystems are especially at risk as high volumes of industrial and urban effluent are discharged into such environments. This not only results in diminished water quality but also greater risk of exposure through consumption of contaminated fish (Castro-González and Méndez-Armenta, 2008). Fish is an important source of protein for humans (Castro-González and Méndez-Armenta, 2008; Chojnacka, 2010) and, as such, ingestion is one route through which humans become exposed to trace elements. The monitoring of element levels within the tissues of fish used for subsistence is therefore of paramount importance to evaluate the risk associated with consumption (Yilmaz, 2003). The manifestation of health effects due to trace element exposure are dependent on the exposure dose and accumulated element concentrations within organisms (Hutton, 1987).

Trace elements can be divided into essential and non-essential elements (De Boek et al., 2010). Essential trace elements are naturally present in all biological systems at low levels and elicit no negative effects on exposure, but at high concentrations these elements do become toxic (De Boek et al., 2010). Non-essential elements are not naturally present in ecosystems and even at low levels are toxic to many organisms (Kalay and Canli, 2000).

To whom all correspondence should be addressed.

Iil +27 11559 2449; Fax +27 11559 2286;

e-mail: aoldewage@uj.ac.za

Received 20 May 2014; accepted in revised form 7 October 2014.
Increases in element levels are especially grave for communities within South Africa due to dwindling water supplies (Blignaut and Van Heerden, 2009). As trace elements, in particular metals and metalloids, are naturally present in aquatic ecosystems, fish and other aquatic organisms are continually exposed to a persistent milieu of elements (Avenant-Oldewage and Marx, 2000; Cui et al., 2001) and this subsequently leads to the accumulation of these substances. Under natural conditions, trace elements are present in low concentrations within the water and are mostly present in sediments (Gouws and Coetzee, 1997; Wepener and Vermeulen, 2005). Adsorption of trace elements in sediment reduces their bioavailability in the environment and thus high sediment trace element levels are not necessarily associated with adverse reactions due to exposure. However, increases in the concentrations within the environment can result in reactions manifesting within all levels of the food chain (Tessier and Campbell, 1987).

Fish exposed to trace elements are able to accumulate these at orders of magnitude greater than the levels in the environment (Nyogi and Wood, 2003; Tan and Wang, 2011), and for this reason the use of fish as sentinels for monitoring element levels has been suggested (Zhou et al., 2008). This invariably results in better accuracy when determining trace element levels in the environment compared to only monitoring concentrations within water (Yamazaki et al., 1996; Zhou et al., 2008). The degree of bioaccumulation in fish is, however, influenced by a number of biotic and abiotic factors, which can alter the accumulation and availability of elements. Physicochemical factors such as $\mathrm{pH}$, temperature and dissolved oxygen have been shown to influence the availability of elements (Van Vuren et al., 1994; Qadir and Malik, 2011). Age, body mass, gender and 


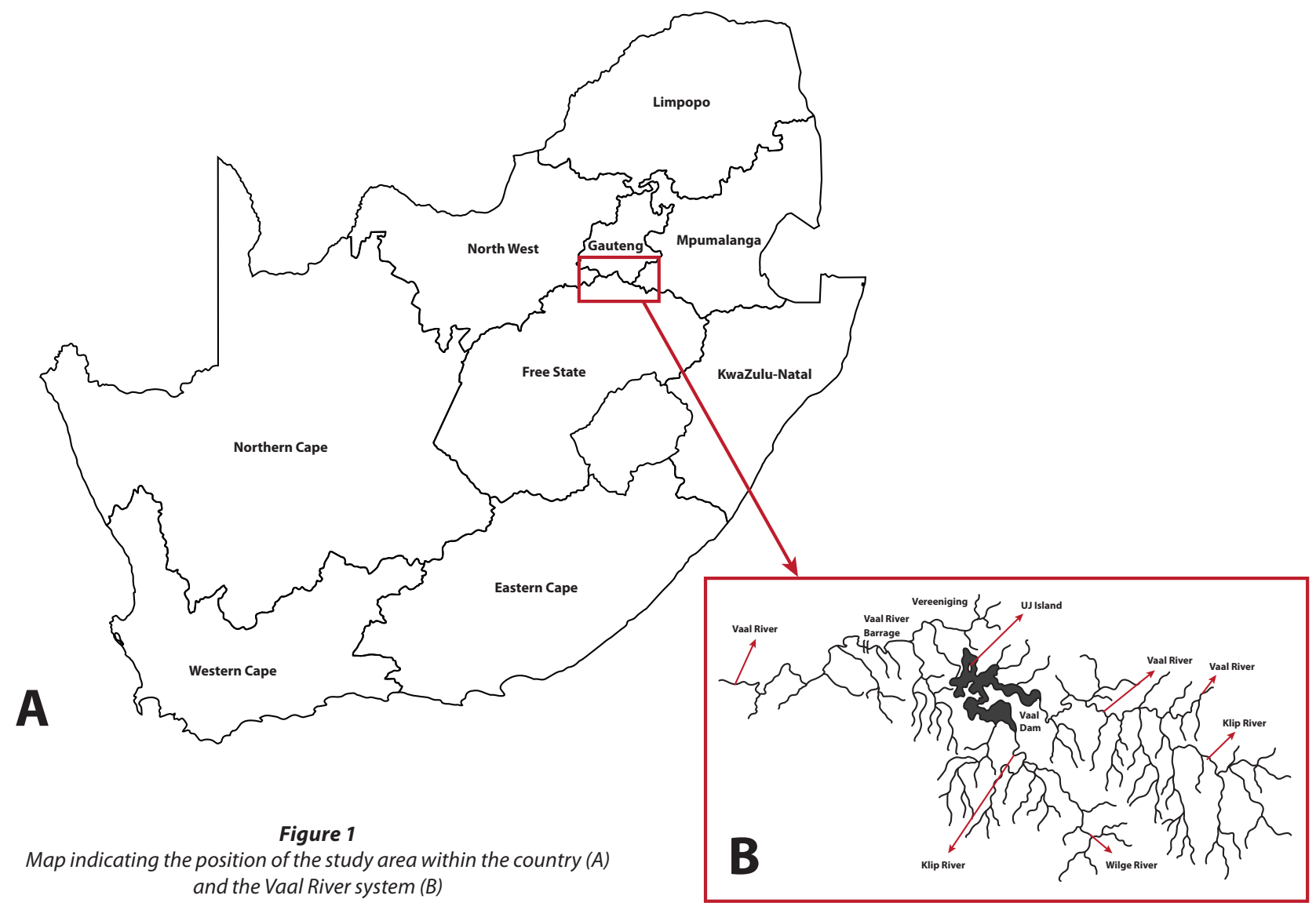

physiological condition of fish (Alhashemi et al., 2011) are a few biological factors which can influence the concentrations of trace elements. Trends in accumulation of elements within fish tissues have been identified in many investigations (Mason et al., 2000; Pedlar et al., 2002; Pedlar and Klaverkamp, 2002; Fu et al., 2010). The liver, kidney and gills are the principle organs involved in accumulation and sequestration of trace elements within fish (e.g. Seymore et al., 1995; Wagener and Boman, 2003; Cao et al., 2012; Squadrone et al., 2013). This has been correlated with the metabolic activity (Squadrone et al., 2013) as well as the presence of specific proteins within each organ (Olafson et al., 1979; Hogstrand and Haux, 1990; Van der Oost et al., 2003; Pan and Zhang, 2006). Muscle and bony tissue on the other hand are relatively inert in terms of trace element accumulation. Matiniaková et al. (2012) demonstrated that analysis of element levels in bone can give an accurate historical record of exposure. This is due to the slow turnover and remodelling rate of bone.

As the (Afrikaans) name suggests, waters of the Vaal River are naturally turbid due to high levels of suspended sediment particles and it is these particles that have a major effect on the water quality of this important river system (Grobler et al., 1987). The Vaal River system (Fig. 1) is often referred to as the "work horse' of South Africa (Braune and Rogers, 1987). This system flows through the industrial heartland of the country and as such receives high volumes of effluent containing trace elements. Additionally, the Vaal Dam supplies water to approximately 11.3 million people (Stats SA, 2011) living within the PretoriaWitwatersrand-Vereeniging (PWV) area. For this reason, continual monitoring of trace element levels within the system is paramount. However, the risk associated with exposure to trace elements does not only apply to drinking water, but also to consuming fish caught in this system. Recent studies have indicated that there has been an increase in fishing pressure on yellowfish species within the system, as well as selling of the fish on roadsides by local fishermen (Brand et al., 2009; personal observation 2011). Labeobarbus kimberleyensis (Gilchrist and Thompson, 1913) is one of the largest cyprinid fish in South Africa (Ellender et al., 2012). For this reason, L. kimberleyensis (largemouth yellowfish) is a renowned angling species and therefore prized by many sports fishermen (Skelton, 2001). In terms of environmental indication, this fish species is extremely sensitive to alterations in the environment and responds to changes in environmental condition. Previous studies on trace element accumulation in L. kimberleyensis (Retief et al., 2009) and Clarias gariepinus Burchell, 1822 (Crafford and AvenantOldewage, 2010, 2011) from the Vaal Dam have provided data on metal accumulation in fish since 1998 (13-year period). The aims of this study were to determine the concentrations of trace elements in the liver, kidney, gills, muscle and spinal cord of $L$. kimberleyensis from the Vaal Dam and in so doing determine risk factors associated with consumption of muscle tissue of this species. Furthermore comparison to previous studies performed in the Vaal Dam will be done to assess fluctuations of elements within the water, sediment and fish from the dam.

\section{MATERIALS AND METHODS}

\section{Sampling}

Sampling was undertaken at the Vaal Dam, around UJ Island (2652.249’ S; $28^{\circ} 10.249^{\prime}$ E). Twenty two (22) L. kimberleyensis 
were caught with the use of gill nets (mesh size: 70-120 mm). Fish were removed from the net, placed into an on-board live well and transported to holding tanks on UJ Island. Fish were weighed and measured before being euthanized by severing the spinal cord, posterior to the head.

Organ samples (muscle, spinal cord, liver, kidney and gills) were removed on dissection with stainless steel instruments and placed into separate plastic, zip-lock bags. The tissue samples were then placed into a freezer $\left(-12^{\circ} \mathrm{C}\right)$ and frozen prior to tissue digestion.

Sediment samples were collected with the use of a grab sampler and stored in polyethylene bottles. The sediment samples were similarly frozen before digestion. Element concentrations in water were acquired from Rand Water Analytical Facility, Vereeniging, South Africa. This establishment performs routine monitoring of the water quality and metal concentrations within the Vaal River system.

\section{Tissue digestion and analysis}

Frozen fish tissue samples were thawed and approximately $1 \mathrm{~g}$ of wet tissue (spinal cord, muscle, liver, kidney and gills) was weighed off in acid-washed, glass Petri dishes, using a Sartorius CP225D scale (readability: 0.01/0.1 mg). The tissue samples were then dried to weight consistency in an oven at $100^{\circ} \mathrm{C}$. Dry samples were then placed in a desiccator cabinet until digestion.

Dried samples were placed into Teflon microwave digestion flasks and treated with $7 \mathrm{~m} \ell$ 65\% Suprapur ${ }^{\circledR}$ nitric acid (Merck, South Africa). Fish tissue digestion was performed using an Ethos Touch Control advance microwave station. Post-digestion the samples were removed from the oven, decanted into $50 \mathrm{~m} \ell$ volumetric flasks and $100 \mu \ell$ of indium $(1000 \mathrm{mg} / \mathrm{kg})$ added as the internal standard. The samples were then diluted to $50 \mathrm{ml}$ with Milli-Q water and stored in $50 \mathrm{~m} \ell$ Cellstar ${ }^{\oplus}$ Tubes (Greiner bio-one) at $4^{\circ} \mathrm{C}$ until analysis. Inductively coupled plasma-mass spectrometry (Thermo Electron Corporation X Series) analysis of the fish tissue was done at the Rand Water Analytical Facility in Vereeniging.

Approximately $0.5 \mathrm{~g}$ of sediment was defrosted, weighed and dried at $50^{\circ} \mathrm{C}$ for $48 \mathrm{~h}$. Sediment samples were leached in Teflon microwave digestion flasks as described for fish samples. Samples were treated with $9 \mathrm{m \ell} 30 \%$ Suprapur ${ }^{\circledR}$ hydrochloric acid (Merck, South Africa) and $3 \mathrm{~m} \ell$ 65\% Suprapur ${ }^{\circledR}$ nitric acid (Merck, South Africa). After digestion, sediment samples were filtered through Millipore filter paper (pore size: $0.1 \mu \mathrm{m}$ ) into acid-washed volumetric flasks and diluted with Milli-Q water $(18.2 \Omega)$ to a volume of $50 \mathrm{~m} \ell$. The diluted samples were decanted and stored in $50 \mathrm{m \ell}$ Cellstar ${ }^{\oplus}$ Tubes (Greiner bio-one). Analysis of sediment samples was done with an inductively coupled plasma mass spectrometer (Thermo Electron Corporation X Series).

For quality control of the analysis of the fish tissue and sediment samples by ICP-MS, certified reference material (CRM) was used. The CRM used for fish tissue was dogfish liver DOLT-4 (NRC, Canada), while Lake Sediment 2 (LKSD 2) CRM (NRC, Canada) was used as the sediment CRM. Triplicate samples of CRM were prepared and treated with the same method as that used for the fish tissue and sediment samples.

\section{Statistical analyses}

\section{Bioconcentration factors (BCF)}

Bioconcentration factors (BCF) were calculated according to the method of Abel (1989), to determine the ratio in element concentrations between fish and environment (water and sediment), as well as to determine the partitioning of elements between different samples. The BCF was calculated as follows:

$$
\begin{aligned}
& B C F=C_{(\text {fish organ) }} / C_{(\text {water })} \\
& B C F=C_{(\text {fish organ) }} / C_{(\text {sediment })}
\end{aligned}
$$

where: the $C_{(\text {fish organ) }}, C_{\text {(sediment) }}$ ( $\mu \mathrm{g} / \mathrm{g}$ dry weight) and $C_{\text {(water) }}$ $(\mu \mathrm{g} / \ell)$ are the fractions of each element in the fish tissues and environment (water and sediment). The BCF was calculated using the median concentration values of each of the elements present in the fish organs, water and sediment.

\section{Element variation between organs}

Statistical analysis of the data obtained by ICP-MS analysis was undertaken with the use of SPSS V. 20 (Statistical Package for the Social Sciences, SPSS Inc.) for Windows. To determine if the element concentrations in the different organs studied were significantly different, the data were analysed using ANOVA. Following this, to determine which specific organ element concentrations were significantly different, a TukeyHSD analysis was performed. Significance in differences was identified if $P<0.05$.

\section{Target hazard quotient}

Target hazard quotients (THQ) were determined to assess the risk people face in consuming flesh of L. kimberleyensis, with regard to the element levels identified in the muscle tissue. The THQ determination serves to identify the ratio between the reference dose and exposure concentration of each element analysed (USEPA, 2013b). THQ was calculated for adults based on the parameters displayed in Table 1 (USEPA, 2013a):

$$
T H Q=\left(E F_{r} \times E D_{r} \times I R F_{a} \times C\right) /\left(R f D_{o} \times B W_{a} \times A T\right)
$$

where:

THQ is the target hazard quotient

$B W_{a}$ is the average body weight of individuals in the adult age class

$A T$ is the average time over which the assessment was undertaken

$E F_{r}$ is the exposure frequency (i.e. the number of days within a year fish is consumed by the study groups) $E D_{r}$ is the duration of the exposure (expressed in years) $I R F_{a}$ is the consumption rate of fish expressed as kilograms per day ( $\mathrm{kg} /$ day).

A body weight of $70 \mathrm{~kg}$ is used as a default value for the adult age group (including pregnant females) as suggested by Heath et al. (2004) and US EPA (2013a). A consumption rate of $54 \mathrm{~g}$ of fish per day was selected as a default value according to US EPA (2013a).

Consumption rates were recalculated to determine how much fish muscle needs to be consumed for adverse health effects to become present. For this THQ values for all elements were assumed to be $1(T H Q=1)$, as at this value and higher health risks associated with consumption of fish are assumed to manifest. Values for $B W_{a}, A T, E F_{r}, E D_{r}$ and $R f D_{o}$ were maintained as indicated in Table 1 . 


\begin{tabular}{|c|c|c|c|c|c|}
\hline \multicolumn{7}{|c|}{ TABLE 1 } \\
\hline & $\begin{array}{c}\text { Average } \\
\text { weight } \\
\text { (kg) }\end{array}$ & $\begin{array}{c}\text { Average } \\
\text { time } \\
\text { (days) }\end{array}$ & $\begin{array}{c}\text { Exposure } \\
\text { frequency } \\
\text { (days/ } \\
\text { year) }\end{array}$ & $\begin{array}{c}\text { Exposure } \\
\text { duration } \\
\text { (years) }\end{array}$ & $\begin{array}{c}\text { Fish } \\
\text { consump- } \\
\text { tion rate } \\
\text { (kg/day) }\end{array}$ \\
\hline & $\mathrm{BW}_{\mathrm{a}}$ & AT & $\mathrm{EF}_{\mathrm{r}}$ & $\mathrm{ED}_{\mathrm{r}}$ & $\mathrm{IRF}_{\mathrm{a}}$ \\
\hline Adult & 70 & 365 & 350 & 30 & 0.054 \\
\hline
\end{tabular}

\begin{tabular}{|l|c|c|c|}
\hline \multicolumn{4}{|c|}{$\begin{array}{c}\text { TABLE } 2 \\
\text { Mean element concentrations recorded for water and } \\
\text { sediment samples collected from the Vaal Dam from } \\
\text { February } 2011 \text { to April } \\
\text { 2011 and detection limits (LOD) for } \\
\text { ICP-MS used }\end{array}$} \\
\hline Metal & Water $(\mu \mathrm{g} / \ell)$ & Sediment $(\mu \mathrm{g} / \mathrm{g})$ & LOD $(\boldsymbol{\mu g} / \mathrm{g})$ \\
\hline $\mathrm{As}$ & B.D & 28.97 & 0.045 \\
\hline $\mathrm{Cr}$ & B.D & 1390.00 & 0.039 \\
\hline $\mathrm{Cu}$ & 10.00 & 157.17 & 0.378 \\
\hline $\mathrm{Fe}$ & 1075.00 & 41200.00 & 2.067 \\
\hline $\mathrm{Mn}$ & 15.00 & 637.00 & 0.056 \\
\hline $\mathrm{Ni}$ & 0.063 & 133.16 & 0.126 \\
\hline $\mathrm{Pb}$ & 0.032 & 49.05 & 0.064 \\
\hline $\mathrm{Se}$ & B.D & 8.54 & 0.253 \\
\hline $\mathrm{Zn}$ & 0.24 & 250.33 & 0.473 \\
\hline $\mathrm{Bb}$ & & & \\
\hline
\end{tabular}

B.D: indicates elements present below detection limit of ICP-MS

\section{RESULTS}

\section{Water and sediment metal concentrations}

Table 2 illustrates the concentrations of trace elements present within the water and sediment. Iron was present in the highest concentrations for both water and sediment; followed by $\mathrm{Cr}$ and $\mathrm{Mn}$ in sediment, and $\mathrm{Mn}$ and $\mathrm{Cu}$ in water. For water, all elements were below the concentrations of those in sediment and As, Cr and Se were below the detection limits of the instrument. The order of trace elements in the sediment and water (in descending order) is: $\mathrm{Fe}>\mathrm{Cr}>\mathrm{Mn}>\mathrm{Zn}>\mathrm{Cu}>\mathrm{Ni}>\mathrm{Pb}>\mathrm{As}>$ $\mathrm{Se}$ (sediment); $\mathrm{Fe}>\mathrm{Mn}>\mathrm{Cu}>\mathrm{Zn}>\mathrm{Ni}>\mathrm{Pb}$ (water).

\section{Trace element bioaccumulation in L. kimberleyensis tissues}

Fish were all of similar size as a gill net was used. Fish sampled were of mean weight $1.001 \pm 0.72 \mathrm{~kg}$ and fork length $46.3 \pm 7.91$ $\mathrm{cm}$. It is assumed that fish of this size are most often caught and consumed by local people, and are of a similar cohort.

The trace element concentrations in muscle, spinal cord, liver, kidney and gills for the largemouth yellowfish from the Vaal Dam are presented (Table 3). Large variation in the concentrations of elements with regard to each organ was present. Normalisation of trace element concentrations in each organ was done by calculating the natural logarithm of the element concentrations in the organs. As a result of the large variances in the element concentrations, the median values have been used to discuss the bioaccumulation of trace elements in $L$. kimberleyensis.

The liver, gills and kidney accumulated most elements at higher concentrations compared to muscle and spinal cord. $\mathrm{Cu}, \mathrm{Fe}, \mathrm{Se}$ and $\mathrm{Zn}$ were accumulated at higher concentrations in the liver compared to the other organs. As, Cr and
TABLE 3

Organ weights $(g)$ and trace element concentrations $(\mu \mathrm{g} / \mathrm{g})$ in the five organs of L. kimberleyensis from the Vaal Dam

\begin{tabular}{|c|c|c|c|c|c|c|}
\hline Element & & $\begin{array}{c}\text { Muscle } \\
(n=22)\end{array}$ & $\begin{array}{c}\text { Spinal } \\
\text { cord } \\
(n=22)\end{array}$ & $\begin{array}{c}\text { Liver } \\
(n=22)\end{array}$ & $\begin{array}{l}\text { Kidney } \\
(n=22)\end{array}$ & $\begin{array}{c}\text { Gills } \\
(n=22)\end{array}$ \\
\hline \multirow{3}{*}{$\begin{array}{l}\text { Organ } \\
\text { weight } \\
\text { (g) }\end{array}$} & Mean & 2.53 & 8.08 & 1.00 & 1.88 & 2.54 \\
\hline & Median & 2.51 & 6.60 & 1.42 & 1.73 & 2.45 \\
\hline & S.D & 0.35 & 4.59 & 0.68 & 1.08 & 0.62 \\
\hline \multirow{3}{*}{$\begin{array}{l}\text { As } \\
(\mu g / g)\end{array}$} & Mean & 0.196 & 0.58 & 0.576 & 1.033 & 0.455 \\
\hline & Median & 0.131 & 0.432 & 0.427 & 0.844 & 0.387 \\
\hline & S.D & 0.178 & 0.535 & 0.35 & 0.521 & 0.325 \\
\hline \multirow{3}{*}{$\begin{array}{l}\mathrm{Cr} \\
(\mu \mathrm{g} / \mathrm{g})\end{array}$} & Mean & 0.387 & 0.278 & 0.434 & 0.292 & 0.25 \\
\hline & Median & 0.198 & 0.124 & 0.213 & 0.271 & 0.259 \\
\hline & S.D & 0.601 & 0.499 & 0.588 & 0.223 & 0.137 \\
\hline \multirow{3}{*}{$\begin{array}{l}\mathrm{Cu} \\
(\mu \mathrm{g} / \mathrm{g})\end{array}$} & Mean & 0.572 & 0.245 & 14.798 & 10.286 & 4.178 \\
\hline & Median & 0.477 & 0.229 & 11.681 & 2.352 & 0.857 \\
\hline & S.D & 0.22 & 0.08 & 12.469 & 35.501 & 15.434 \\
\hline \multirow{3}{*}{$\begin{array}{l}\mathrm{Fe} \\
(\mu \mathrm{g} / \mathrm{g})\end{array}$} & Mean & 23.433 & 20.176 & 154.454 & 26.116 & 107.609 \\
\hline & Median & 8.903 & 8.368 & 113.218 & 1.117 & 61.495 \\
\hline & S.D & 51.878 & 27.743 & 331.862 & 44.244 & 204.291 \\
\hline \multirow{3}{*}{$\begin{array}{l}\mathrm{Mn} \\
(\mu \mathrm{g} / \mathrm{g})\end{array}$} & & 1.524 & 1.256 & 2.085 & 0.794 & 8.254 \\
\hline & Median & 0.346 & 0.664 & 1.826 & 0.807 & 1.925 \\
\hline & S.D & 5.125 & 2.205 & 0.821 & 0.32 & 28.913 \\
\hline \multirow{3}{*}{$\begin{array}{l}\mathrm{Ni} \\
(\mu \mathrm{g} / \mathrm{g})\end{array}$} & Mean & 0.251 & 0.095 & 0.392 & 0.37 & 0.158 \\
\hline & Median & 0.184 & 0.084 & 0.236 & 0.251 & 0.164 \\
\hline & S.D & 0.264 & 0.057 & 0.521 & 0.255 & 0.078 \\
\hline \multirow{3}{*}{$\begin{array}{l}\mathrm{Pb} \\
(\mu \mathrm{g} / \mathrm{g})\end{array}$} & Mean & 0.101 & 0.012 & 0.119 & 0.086 & 0.165 \\
\hline & Median & 0.092 & 0.011 & 0.087 & 0.063 & 0.198 \\
\hline & S.D & 0.048 & 0.004 & 0.117 & 0.09 & 0.073 \\
\hline \multirow{3}{*}{$\begin{array}{l}\text { Se } \\
(\mu g / g)\end{array}$} & Mean & 0.675 & 0.224 & 2.736 & 1.309 & 0.455 \\
\hline & Median & 0.653 & 0.197 & 2.566 & 1.187 & 0.453 \\
\hline & S.D & 0.156 & 0.07 & 0.779 & 0.715 & 0.192 \\
\hline \multirow{3}{*}{$\begin{array}{l}\mathrm{Zn} \\
(\mu \mathrm{g} / \mathrm{g})\end{array}$} & Mean & 45.428 & 25.42 & 44.931 & 37.275 & 40.371 \\
\hline & Median & 13.114 & 4.538 & 32.595 & 24.961 & 0.687 \\
\hline & S.D & 132.087 & 51.619 & 47.623 & 40.676 & 57.354 \\
\hline
\end{tabular}

Ni levels were highest in the kidney, while $\mathrm{Mn}$ and $\mathrm{Pb}$ levels were highest in the gill tissue. Muscle and spinal cord demonstrated lowest accumulation in most cases. An exception to this trend is that of $\mathrm{Pb}$ in the muscle tissue and $\mathrm{As}$ in the spinal cord. It should be noted that when referring to the gills and spinal cord tissue in the present study, this includes both bony (gills - arch; spinal cord - vertebrae) and soft (gills filaments; spinal cord - neural cord) tissues comprising these organs. Furthermore, regarding the accumulation of metals within the same organ, it was seen that the concentrations differ (Table 3). Results of an ANOVA test showed that the concentrations of $\mathrm{Cr}, \mathrm{Fe}, \mathrm{Pb}$ and $\mathrm{Zn}$ did not significantly differ $(P>0.05)$ between any of the organs while the other elements analysed for did significantly differ $(P<0.05)$ between the organs studied.

To determine which organ groups differed significantly according to the element concentration in each (according to results of ANOVA) a Tukey-HSD post-hoc test was performed (Table 4). Results of the post-hoc test revealed that in all comparisons between the organ groupings concentrations of $\mathrm{Cr}, \mathrm{Fe}$, $\mathrm{Pb}$ and $\mathrm{Zn}$ did not significantly differ. These results support the differences observed in the accumulation of metals outlined from Table 3 previously. 
TABLE 4

Significant differences $(P<0.05)$ in trace element concentrations between organ groups calculated using a Tukey-HSD test

\begin{tabular}{|l|l|c|c|c|c|c|c|c|c|c|}
\hline Organ & & $\mathrm{As}$ & $\mathrm{Cr}$ & $\mathrm{Cu}$ & $\mathrm{Fe}$ & $\mathrm{Mn}$ & $\mathrm{Ni}$ & $\mathrm{Pb}$ & $\mathrm{Se}$ & $\mathrm{Zn}$ \\
\hline \multirow{3}{*}{ Muscle } & Spinal cord & 0.000 & 0.884 & 0.874 & 0.999 & 0.868 & 0.119 & 0.944 & 0.000 & 0.533 \\
\cline { 2 - 12 } & Liver & 0.000 & 0.989 & 0.000 & 0.736 & 0.005 & 0.446 & 0.262 & 0.000 & 1.000 \\
\cline { 2 - 12 } & Kidney & 0.000 & 0.995 & 0.001 & 0.875 & 0.979 & 0.355 & 1.000 & 0.000 & 0.999 \\
\cline { 2 - 12 } & Gills & 0.000 & 0.948 & 0.658 & 0.502 & 0.001 & 0.761 & 0.379 & 0.129 & 0.946 \\
\hline \multirow{3}{*}{ Spinal cord } & Liver & 0.999 & 0.618 & 0.000 & 0.638 & 0.082 & 0.001 & 0.051 & 0.000 & 0.517 \\
\cline { 2 - 12 } & Kidney & 0.000 & 0.983 & 0.000 & 0.932 & 0.994 & 0.000 & 0.963 & 0.000 & 0.624 \\
\cline { 2 - 11 } & Gills & 0.837 & 0.999 & 0.150 & 0.404 & 0.020 & 0.731 & 0.088 & 0.020 & 0.927 \\
\hline \multirow{2}{*}{ Liver } & Kidney & 0.002 & 0.905 & 0.002 & 0.196 & 0.029 & 0.999 & 0.226 & 0.000 & 0.999 \\
\cline { 2 - 11 } & Gills & 0.744 & 0.740 & 0.000 & 0.996 & 0.983 & 0.039 & 0.999 & 0.000 & 0.940 \\
\hline Kidney & Gills & 0.000 & 0.997 & 0.074 & 0.088 & 0.006 & 0.026 & 0.334 & 0.000 & 0.975 \\
\hline
\end{tabular}

\begin{tabular}{|c|c|c|c|c|c|c|c|c|c|c|}
\hline \multicolumn{11}{|c|}{$\begin{array}{c}\text { TABLE } 5 \\
\text { BCF values calculated between median trace element concentrations in water and sediment compared to L. kimberleyensis } \\
\text { organ levels from the Vaal Dam }\end{array}$} \\
\hline \multirow[t]{2}{*}{ Element } & \multicolumn{5}{|c|}{ Water } & \multicolumn{5}{|c|}{ Sediment } \\
\hline & Muscle & Spinal cord & Liver & Kidney & Gills & Muscle & Spinal cord & Liver & Kidney & Gills \\
\hline As & N.D & N.D & N.D & N.D & N.D & 0.0045 & 0.015 & 0.015 & 0.029 & 0.013 \\
\hline $\mathrm{Cr}$ & N.D & N.D & N.D & N.D & N.D & 0.0001 & 0.0001 & 0.0002 & 0.0002 & 0.0002 \\
\hline $\mathrm{Cu}$ & 0.057 & 0.025 & 1.48 & 1.029 & 0.418 & 0.003 & 0.002 & 0.074 & 0.015 & 0.006 \\
\hline $\mathrm{Fe}$ & 0.0218 & 0.0188 & 0.144 & 0.0243 & 0.100 & 0.0002 & 0.0002 & 0.003 & 0.000 & 0.002 \\
\hline $\mathrm{Mn}$ & 0.102 & 0.0837 & 0.139 & 0.0529 & 0.550 & 0.0005 & 0.001 & 0.003 & 0.001 & 0.003 \\
\hline $\mathrm{Ni}$ & 2.921 & 1.333 & 3.746 & 3.984 & 2.603 & 0.001 & 0.001 & 0.002 & 0.002 & 0.001 \\
\hline $\mathrm{Pb}$ & 2.875 & 0.344 & 2.719 & 1.969 & 6.188 & 0.002 & 0.0002 & 0.002 & 0.001 & 0.004 \\
\hline $\mathrm{Se}$ & N.D & N.D & N.D & N.D & N.D & 0.077 & 0.023 & 0.301 & 0.139 & 0.053 \\
\hline $\mathrm{Zn}$ & 54.642 & 18.908 & 135.813 & 104.004 & 2.536 & 0.052 & 0.018 & 0.13 & 0.1 & 0.002 \\
\hline
\end{tabular}

N.D: BCF value not available as elements were below detection in water samples

\section{Bioconcentration factors}

Calculation of BCF values (Table 5) for trace elements in water and sediment compared with organs of L. kimberyleyensis indicate that $\mathrm{Zn}, \mathrm{Ni}$ and $\mathrm{Pb}$ levels are present in higher concentrations in fish tissue compared to the water $(B C F>1)$, but in lower concentrations compared to the sediment $(B C F<1)$; while $\mathrm{Mn}, \mathrm{Cu}$ and $\mathrm{Fe}$ were higher in water compared to fish tissue. Bioconcentration factors (BCF) could not be determined (N.D) for As, Cr, and Se in water as these elements were below the detection limits of the instrumentation.

\section{Health risk calculations}

Target hazard quotients (THQ) were calculated for the various elements in the muscle tissue of L. kimberleyensis from the median element concentrations and are presented in Table 6 . THQ values are presented based on the average weight of adults being $70 \mathrm{~kg}$ (including pregnant females). Most elements do not demonstrate risk associated with consumption $(T H Q<1)$ of $54 \mathrm{~g}$ of L. kimberleyensis flesh, except for $\mathrm{Cr}$ and Se.

Furthermore, values were calculated for the amount of fish which would have to be consumed $\left(I R F_{b}\right)$ for each element for health risks to become evident (THQ $>1)$. These calculated values indicate that a small amount of fish would be needed to produce adverse health effects for $\mathrm{As}, \mathrm{Cr}, \mathrm{Pb}, \mathrm{Se}$, and $\mathrm{Zn}$, while larger amounts of fish will need to be consumed for health risk to be associated with $\mathrm{Cu}, \mathrm{Fe}, \mathrm{Mn}$ and $\mathrm{Ni}$.

\section{DISCUSSION}

\section{Water and sediment}

Water sample analysis indicated that most elements were present in lower concentrations compared to sediment levels and fish tissue concentrations. Levels of $\mathrm{Mn}$ and Fe in water, however, were greater than the fish tissue element levels and $\mathrm{Cu}$ in water was greater than the concentrations in muscle, spinal cord and gills. This result is similar to previous studies by Crafford and Avenant-Oldewage $(2010 ; 2011)$ for As, Cr and $\mathrm{Se}$, which were below detection, but $\mathrm{Fe}, \mathrm{Mn}$ and $\mathrm{Cu}$ levels were higher. Compared to Retief et al. (2009), the concentrations of all elements in water from the present study and those of Crafford and Avenant-Oldewage $(2010 ; 2011)$ were lower, except for $\mathrm{Fe}, \mathrm{Mn}$ and $\mathrm{Cu}$ which were higher. Sample collection by Retief et al. (2009) and Crafford and Avenant-Oldewage (2010; 2011) was done during the years 2006 and 1998-2000 respectively. Samples for the current study were collected in 2011. Comparison of these data with the present illustrates a time line over a period of 13 years for which fluctuations in 
TABLE 6

Target hazard quotients (THQ) for elements measured in L. kimberleyensis muscle tissue, from the Vaal Dam ( $\mathrm{ffD}_{\mathrm{o}^{\prime}}$, Reference oral dosage according to US EPA (2013b))

\begin{tabular}{|c|c|c|c|c|c|c|c|c|c|c|c|}
\hline & $B W_{a}(\mathrm{~kg})$ & $I R F_{a}$ (kg/day) & As & $\mathrm{Cr}$ & $\mathrm{Cu}$ & $\mathrm{Fe}$ & $\mathrm{Mn}$ & $\mathrm{Ni}$ & $\mathrm{Pb}$ & $\mathrm{Se}$ & $\mathrm{Zn}$ \\
\hline$R f D_{0}$ (mg/kg per day) & & & 0.0003 & 0.003 & 0.04 & 0.7 & 0.14 & 0.02 & $0.0036^{*}$ & 0.005 & 0.3 \\
\hline THQ & 70.0 & 0.054 & 0.962 & 1.465 & 0.265 & 0.282 & 0.0548 & 0.204 & 0.567 & 2.898 & 0.970 \\
\hline$I R F_{b}(\mathrm{~kg} /$ day $)$ & 70.0 & - & 0.0562 & 0.0368 & 0.204 & 0.191 & 0.985 & 0.264 & 0.0952 & 0.0186 & 0.0557 \\
\hline
\end{tabular}

${ }^{*}$ RfD value according to Chan et al. (2011)

Bold values indicate potential risk associated with consumption of L. kimberleyensis muscle at $54 \mathrm{~g}$ per day

element levels within the water are evident. Element levels increased between 1998 and 2006, and subsequently decreased between 2006 and 2011. The decrease in element concentrations in Vaal Dam water can be related to floods that took place shortly before the current study was undertaken. The larger volumes of water within the dam may have resulted in dilution of elements (Avenant-Oldewage and Marx, 2000). Detectable concentrations of $\mathrm{Fe}, \mathrm{Mn}, \mathrm{Cu}, \mathrm{Zn}, \mathrm{Ni}$ and $\mathrm{Pb}$ can be related to high content of suspended clay particles in the water column (Gouws and Coetzee, 1997). All analyte levels recorded in the present study are below target water quality ranges (TWQR) set out by the Department of Water Affairs (former DWAF) for water bodies in South Africa (DWAF, 1996).

Clay minerals are known to have high sorption affinities for a variety of trace elements, especially $\mathrm{Cr}, \mathrm{Cu}, \mathrm{Fe}, \mathrm{Ni}$ and Zn (McLean and Bledsoe, 1992), and thus high levels of these analytes can be related to the composition of the sediments in the catchment. A study by Gouws and Coetzee (1997) demonstrated that these elements are present at higher levels in the Vaal Dam and Wepener et al. (2011) confirmed that the sediments of the Vaal Dam are composed mostly of fine particles which are indicative of high clay content. Comparing the data for elements in the sediment from Retief et al. (2009) and Crafford and Avenant-Oldewage (2011), it is evident that the level of $\mathrm{Fe}$ in sediment has remained higher compared to other elements. Trends in element distribution within sediments have remained fairly constant, but individual element concentrations have increased since 1998. This may be related to the use of the dam for recreational purposes as well as natural processes occurring within the system. Petroleum fuels used by motor boats and cars contain most of the trace elements analysed for in the specific study (Khuhawar et al., 2012). Furthermore, natural weathering of rocks in the upper reaches of the catchment can similarly lead to elevated metal concentrations (Chutter, 1963; Retief et al., 2009). As the study site is located near the dam wall, large volumes of sediment may become deposited as water flow decreases, leading to an increase in element levels.

\section{Fish element levels}

Accumulation of trace elements in the organs of L. kimberleyensis is variable, between organs and between elements within the same organ. The present work demonstrates that the liver, kidney and gills of L. kimberleyensis display the highest accumulation potential for all trace elements analysed, while the muscle and spinal cord have poor accumulation capacity. Similarly, for the Vaal Dam Retief et al. (2009) in L. kimberleyensis and Crafford and Avenant-Oldewage $(2010 ; 2011)$ in C. gariepinus demonstrated higher accumulation of elements in the liver. In both the former- and latter-mentioned studies $\mathrm{Fe}, \mathrm{Cu}, \mathrm{Zn}$ and Se were accumulated at higher concentrations in the liver of both fish species compared to other organs. Comparison of the concentrations of these elements to those found by Crafford and Avenant-Oldewage $(2010 ; 2011)$ indicates that the sharptooth catfish (C. gariepinus) accumulated elements at higher levels than the largemouth yellowfish. This finding for catfish was similarly shown by Pheiffer et al. (2014), who collected C. gariepinus along the Vaal River, below the dam wall. Of all of the analytes measured in L. kimberleyensis, Fe was accumulated in higher concentrations in all organs. Retief et al. (2006) and Crafford and Avenant-Oldewage (2010; 2011) similarly noted this. Visnjic-Jeftic et al. (2010) also found $\mathrm{Cu}, \mathrm{Fe}$ and $\mathrm{Zn}$ to be elevated in the liver compared to other organs in Alosa immaculata Bennett. 1835.

Arsenic, $\mathrm{Cr}$ and Ni levels in kidney were present at the highest levels of all organs studied. Fargar et al. (1995) showed that As was accumulated to higher levels in the kidney (2.26 $\mu \mathrm{g} / \mathrm{g}$ ) than in the other organs sampled in field investigations. Palaniappan and Karthikeyan (2009) similarly demonstrated that kidney tissue accumulated $\mathrm{Cr}(97.326 \mu \mathrm{g} / \mathrm{g}$ and 162.637 $\mu \mathrm{g} / \mathrm{g})$ and $\mathrm{Ni}(116.824 \mu \mathrm{g} / \mathrm{g})$ at even higher concentrations than the liver (Cr: $36.240 \mu \mathrm{g} / \mathrm{g} ; \mathrm{Ni}: 96.314 \mu \mathrm{g} / \mathrm{g}$ ). A laboratory study by Cockell et al. (1991) also demonstrated that As levels in the kidneys of exposed fish were higher $(5.71 \mu \mathrm{g} / \mathrm{g})$ than in the liver $(3.25 \mu \mathrm{g} / \mathrm{g})$. Other studies, however, have shown that As and Cr predominantly accumulated in the muscle and gills of fish (e.g. Takatsu et al. 1999; Squadrone et al., 2013). This is dissimilar to what was observed in the present study. According to Pedlar et al. (2002), the kidney serves as an important site for As accumulation. Both kidney and liver are involved in the detoxification of the body. The liver is the principle detoxification organ, while the kidney may be secondary in function. Elements accumulating in the kidney of fish initially become bound to proteins in the liver which are then transported to the kidney and become sequestered. This has been demonstrated by Squadrone et al. (2013) for Cd and may possibly also hold true for other elements.

Some elements $(\mathrm{Pb}$ and $\mathrm{Mn})$ accumulated in higher concentrations in the gills. Squadrone et al. (2013) indicated that higher $\mathrm{Pb}$ concentrations in the gills were related to the lower $\mathrm{pH}$ at the gill surface as a result of high carbon dioxide levels. The lower $\mathrm{pH}$ is thought to increase the solubility of $\mathrm{Pb}$ and allow it to easily diffuse across the gill surface (Squadrone et al., 2013). Furthermore, the analysis of the gill tissue in the present study incorporated the gills as a whole, i.e., the bony arch and filaments. Crafford and Avenant-Oldewage (2010) found that both $\mathrm{Ni}$ and $\mathrm{Pb}$ were accumulated in significantly higher concentrations in the gill arches compared to the filaments. Elevated Mn concentrations in the gills was similarly shown for the Lowveld largescale yellowfish by Seymore et al. (1995) and was also attributed to accumulation in the bony arch of the gills. This process may take place as a result of trace elements competing with $\mathrm{Ca}$ for binding to the bony structures and becoming incorporated into bone in place of Ca (Hunn, 1985; Martiniaková et al., 2012). Accumulation trends for Mn and $\mathrm{Pb}$ in gill and spinal cord of L. kimberleyensis are similar, even 
though median concentrations for these elements differed. The accumulation of these two elements is therefore most probably a function of competition with Ca for binding within the arch rather than the lower $\mathrm{pH}$ at the gill surface. Lower $\mathrm{pH}$ may still aid in increasing the solubility of both elements and facilitate accumulation in this region.

Muscle tissue, like spinal cord, demonstrated poor accumulation of trace elements. Lower concentrations in muscle tissue can be related to the lower metabolic activity of this organ compared to the gills, kidney and liver (Squadrone et al., 2013). The elemental composition of muscle tissue of L. kimberleyensis demonstrated that $\mathrm{Zn}$ and $\mathrm{Fe}$ were accumulated to a greater extent than the other elements analysed. Other studies within the Vaal River system similarly showed that these analytes were found at higher levels than other elements for this organ. The concentrations of Fe in the muscle of L. kimberleyensis in the present study were higher than those recorded by Retief et al. (2009) $(3.67 \mu \mathrm{g} / \mathrm{g})$ and Pheiffer et al. (2014) $(1.73 \mathrm{mg} / \mathrm{kg})$, but lower than the concentrations reported by Crafford and Avenant-Oldewage (2011), who recorded $63.29 \mu \mathrm{g} / \mathrm{g}$ Fe in muscle tissue of C. gariepinus. For $\mathrm{Zn}$ the concentrations were higher than those recorded for other studies in the Vaal Dam and Vaal River (Retief et al., 2009; Crafford and Avenant-Oldewage, 2011; Wepener et al., 2011; Pheiffer et al., 2014). Most bioaccumulation studies have focused on element levels in the muscle tissue, due to the implications of these regarding human health.

\section{Bioconcentration}

Results of the bioconcentration of elements confirmed that concentrations in L. kimberleyensis were greater than those in the water, but lower than those in the sediment. According to McGeer et al. (2003) calculation of BCF values serves not only as an indication of how many times greater a pollutant is in the biota compared to the environment, but also as a means of determining the partitioning between fish and the environment. Most BCF values could not be calculated for water compared to fish organs as most elements were below detection limits in the water. The higher concentrations of analytes in sediment, which contribute to the lower BCF values, can be attributed to the fact that sediments function as natural 'sinks' within aquatic ecosystems (Wepener and Vermeulen, 2005) and reduce the bioavailable fraction of the element in the environment. Trace elements will thus either not be accumulated or a smaller fraction will be accumulated by biota. The differences in BCF between the water and sediment can additionally result from the dietary habits of L. kimberleyensis. Largemouth yellowfish is a pelagic fish, feeding on a variety of macroinvertebrates and smaller fish species, spending little time within the benthos (Skelton, 2001). Trace element accumulation is therefore predominantly via ingestion of food and diffusion across gill surfaces. With regard to the edibility of certain fish species, Belger and Forsberg (2006) suggest that humans feeding on fish should avoid predatory species and where possible preferentially eat omnivorous ones.

\section{Edibility}

Increased concentrations of trace elements in muscle of $L$. kimberleyensis have implications with regard to consumption by humans. According to Brand et al. (2009) there has been an increase in fishing pressure on yellowfish in the Vaal River system as a food source. This is further supported by personal observations made en route to the study site, where local people were selling fish caught in the Vaal Dam. For this reason, risk factors associated with consumption of L. kimberleyensis were calculated from the data and health risks were assessed according to THQ values. It should be mentioned that these values represent a hypothetical risk and not an actual one. This is because no data were collected from surveys to determine the average weight of adults within the immediate area of the Vaal system, along with consumption rates or amount of fish consumed on a daily basis. The parameters used are therefore based on generalised body weights (70 kg) (Heath et al., 2004) and amounts of fish ( $0.054 \mathrm{~kg}$ flesh) consumed over a 30 -year period (Table 1) as prescribed by the US EPA (2013a). The values calculated in this study further imply that for there to be such a risk, humans consuming L. kimberleyensis from the Vaal Dam would have to eat a mean amount of $54 \mathrm{~g} /$ day of fish flesh over a 30 -year period. In reality the scenario may actually be very different. THQ values less than 1 indicate a low likelihood that individuals consuming fish will experience adverse effects (Liu et al., 2009).

Calculation of hazard quotient values indicates low risk for most trace elements with regard to consumption of L. kimberleyensis flesh. High risk values are associated with $\mathrm{Cr}$ and Se. The risk assessment was further applied to the concentrations of trace elements analysed by Retief et al. (2009). Similarly most elements analysed by the authors demonstrated low risk, except for As, under the same parameters. Risk values in the current study were for the most part higher than those reported by Retief et al. (2009) and further support the observed increase in element concentrations within L. kimberleyensis muscle tissue. Otachi et al. (2014) similarly observed that THQ values for most elements indicated low risk with regard to consumption of the flesh of the blue spotted tilapia from Kenya.

The amount of fish consumed daily to produce a THQ value of 1 was calculated for each element. The value was chosen as it is the absolute minimum value indicating potential risk from consumption of fish. It was determined that for Se, As, Cr, $\mathrm{Zn}$ and $\mathrm{Pb}$ (range: $0.018-0.095 \mathrm{~kg} /$ day) less fish consumed on a daily basis is required to produce adverse health effects compared to $\mathrm{Fe}, \mathrm{Cu}, \mathrm{Ni}$ and $\mathrm{Mn}$ (range: $0.19-0.98 \mathrm{~kg} /$ day) which require larger amounts of muscle tissue to be eaten. Therefore if consumption rates of fish increased to approximately $0.985 \mathrm{~kg} /$ day adverse health effects related to all elements would become evident, provided element concentrations in L. kimberleyensis muscle remains constant. Furthermore, if consumption rates had to increase only slightly along with element levels, individuals feeding on L. kimberleyensis would experience adverse effects within a shorter period of time.

Compared to the maximum permissible limits for elements in food prescribed by the European Commission (2006) and joint codex on food safety by FAO/WHO (2011), the concentrations of most elements recorded in the present study are below these limits, except for Se (limit: $0.3 \mathrm{mg} / \mathrm{kg}$ ). Permissible limits for $\mathrm{Cr}$ in fish flesh have not been set out. This further supports the low risk associated with consumption for most elements, except for Cr and Se. Element levels in Retief et al. (2009) were similarly below these prescribed thresholds. At such levels it is considered that there will not be health risks associated with the consumption of largemouth yellowfish (EU 2006), from the Vaal Dam in the present study.

\section{CONCLUSION}

Trace element concentrations in sediment have increased over a 13-year period; however, element distributions have remained 
constant due to the mineralogy of the catchment. Liver accumulated the highest concentrations for most elements. These findings correspond with most investigations indicating that liver tissue of fish should be incorporated into bioaccumulation assessments as it is a good bioindicator for most trace elements. Furthermore, over a 5 -year period it is evident that element levels in L. kimberleyensis tissue have also increased. Health risks associated with consumption of yellowfish muscle tissue are low, except for $\mathrm{Cr}$ and Se. This, however, should be checked using accurate parameters for local populations eating fish caught in the Vaal River system. Although L. kimberleyensis demonstrates potential for accumulating trace elements, the values recorded are below those for C. gariepinus from the Vaal Dam. For this reason it is recommended that the concentrations within the tissues of this species be checked to determine if this trend is maintained. Furthermore, it is recommended that any further study conducted on trace element accumulation of any fish species within the Vaal River system should be accompanied by accurate determination of the risk factors for people dependent on fish as a regular food source.

\section{ACKNOWLEDGEMENTS}

Prof HH du Preez is thanked for assistance with obtaining water quality data from Rand Water. Mr H Foden of the Rand Water Analytical Facility is thanked for undertaking sample analysis on the ICP-MS. The NRF is thanked for providing funding for the work presented. The University of Johannesburg is acknowledged for providing necessary facilities and funding for the undertaking and completion of the present work.

\section{REFERENCES}

ABEL PD (1989) Pollutant toxicity to aquatic animals - Methods of study and their applications. Rev. Environ. Health 8 119-155.

ALHASHEMI AH, KARBASSI A, KIABI BH, MONAVARI SM and SEKHAVATJOU MS (2011) Bioaccumulation of trace elements in different tissues of three commonly available fish species regarding their gender, gonadosomatic index, and condition factor in a wetland ecosystem. Environ. Monit. Assess. DOI 10.1007/ s10661-011-2085-8.

AVENANT-OLDEWAGE A and MARX HM (2000) Bioaccumulation of chromium, copper and iron in the organs and tissues of Clarias gariepinus in the Olifants River, Kruger National Park. Water SA 26 (4) 569-582.

BELGER L and FORSBERG BR (2006) Factors controlling Hg levels in two predatory fish species in the Negro river basin, Brazilian Amazon. Sci. Total Environ. 36 451-459.

BLIGNAUT J and VAN HEERDEN J (2009) The impact of water scarcity on economic development initiatives. Water SA 35 (4) 415-420.

BRAND M, MAINA J, MANDER M and O'BRIEN G (2009) Characterisation of the social and economic value of the use and associated conservation of the yellowfishes in the Vaal River. WRC Report No. KV 226/09. Water Research Commission, Pretoria.

BRAUNE E and ROGERS KH (1987) The Vaal River catchment: Problems and research needs. South African National Scientific Programmes, Report No. 143. FRD/CSIR, Pretoria.

CAO L, HUANG W, SHAN X, YE Z and DOU S (2012) Tissue specific accumulation of cadmium and its effects on antioxidative responses in Japanese flounder juveniles. Environ. Toxicol. Pharmacol. 33 16-25.

CASTRO-GONZÁLEZ MI and MÉNDEZ-ARMENTA M (2008) Heavy metals: Implications associated with fish consumption. Environ. Toxicol. Pharmacol. 26 263-271.

CHOJNACKA K (2010) Biosorption and bioaccumulation - the prospects for practical applications. Environ. Int. 36 299-307.
CHUTTER FM (1963) Hydrobiological studies on the Vaal River in the Vereeniging area, Part I. Introduction: water chemistry and biological studies on the fauna of habitats other than muddy bottom sediments. Hydrobiologia 21 1-65.

COCKELL KA, HILTON JW and BETTGER WJ (1991) Chronic toxicity of dietary arsenic heptahydrate to juvenile rainbow trout (Oncorhynchus mykiss). Arch. Environ. Contam. Toxicol. 21 518-527.

CRAFFORD D and AVENANT-OLDEWAGE A (2010) Bioaccumulation of non-essential trace metals in tissues and organs of Clarias gariepinus (sharptooth catfish) from the Vaal River system - strontium, aluminium, lead and nickel. Water SA 36 (5) 621-640.

CRAFFORD D and AVENANT-OLDEWAGE A (2011) Uptake of selected metals in tissues and organs of Clarias gariepinus (sharptooth catfish) from the Vaal River System - chromium, copper, iron, manganese and zinc. Water SA 37 (2) 181-200.

CUI B, ZHANG Q, ZHANG K, LIU X and ZHANG H (2001) Analyzing trophic transfer of heavy metals for food webs in the newly - formed wetlands of the Yellow River Delta, China. Environ. Pollut. 159 1297-1306.

DE BOEK G, EYCKMANS M, LARDON I, BOBBAERS R, SINHA AK and BLUST R (2010) Metal accumulation and metallothionein induction in the spotted dogfish Scyliorhinus canicula. Comp. Biochem. Physiol. Part A 155 503-508.

DWA (DEPARTMENT OF WATER AFFAIRS, SOUTH AFRICA) (2010) Vaal Dam. URL: http://www.dwaf.gov.za/orange/vaal/vaaldam.aspx (Last updated June, 2013) (Accessed 1 May 2014).

DWAF (DEPARTMENT OF WATER AFFAIRS AND FORESTRY, SOUTH AFRICA) (1996) South African Water Quality Guidelines ( $1^{\text {st }}$ edn.) Volume 7: Aquatic Ecosystems. DWAF, Pretoria.

ELLENDER BR, WEYL OLF and WINKER H (2012) Age and growth and maturity of southern Africa's largest cyprinid fish, the largemouth yellowfish Labeobarbus kimberleyensis. J Fish Biol. 81 1271-1284.

EUROPEAN COMMISSION (EU) (2006) Regulation (EC) No. $1881 / 2006$ of 19 December 2006 setting maximum levels for certain contaminants in food stuffs. URL: http://faolex.fao.org/docs/pdf/ eur68134.pdf (Accessed 22 March 2014).

FAO/WHO (FOOD AND AGRICULTURE ORGANISATION/ WORLD HEALTH ORGANISATION) (2011) Report of the fifth session of the Codex Committee on contaminants in foods. Codex Alimentarius Commission, Rome. URL: ftp://ftp.fao.org/codex/ reports/reports 2012/REP12 CFe.pdf(Accessed 28 March 2014).

FARGAR AM, STRANSBURY MA, HOGSTRAND C, MACCONNELL E and BERGMAN H (1995) The physiological impairment of free-ranging brown trout exposed to metals in the Clark Fork River, Montana. Can. J. Fish. Aquat. Sci. 25 2038-2050.

FU Z, WU F, AMARASIRIWARDENA D, MO C, LIU B, ZHU J, DENG Q and LIAO H (2010) Antimony, arsenic and mercury in the aquatic environment and fish in a large antimony mining area in Hunan, China. Sci. Total Environ. 408 3403-3410.

GOUWS K and COETZEE PP (1997) Determination and partitioning of heavy metals in sediments of the Vaal Dam System by sequential extraction. Water SA 23 217-226.

GROBLER DC, TOERIEN DF and ROSSOUW JN (1987) A review of sediment/water quality interaction with particular reference to the Vaal River system. Water SA 13 15-22.

HANS-SCHÖN E, BOGUT I and STRELEC I (2006) Heavy metal profile in five fish species included in human diet, domiciled in the end flow of River Neretva (Croatia). Arch. Environ. Contam. Toxicol. 50 545-551.

HEATH R, DU PREEZ H, GENTHE B and AVENANT-OLDEWAGE A (2004) Freshwater Fish and Human Health Reference Guide. WRC Report No. TT 212/04. Water Research Commission, Pretoria.

HOGSTRAND C and HAUX C (1991) Binding and detoxification of heavy metals in lower vertebrates with reference to metallothionein. Comp. Biochem. Physiol. Part C 100 137-141.

HUNN JB (1985) Role of calcium in gill function in freshwater fishes. Comp. Biochem. Physiol. Part A 82 543-547.

HUTTON M (1987) Human health concerns of lead, mercury, cadmium and arsenic. In: Hutchinson TC and Meema KM (eds) Lead, 
Mercury, Cadmium and Arsenic in the Environment. John Wiley and Sons, New York.

KALAY M and CANLI M (2000) Elimination of essential (Cu, Zn) and non-essential $(\mathrm{Cd}, \mathrm{Pb})$ metals from tissues of a freshwater fish Tilapia zilli. Turk. J. Zool. 24 429-436.

KHUHAWAR MY, ASLAM MIRZA M and JAHANGIR TM (2012) Determination of metal ions in crude oils, crude oil emulsionscomposition stability and characterization. In: Abdul-Raouf ME-S(ed.) Crude oil emulsions - composition stability and characterisation. InTech, Croatia DOI 10.5772/36945. URL: http://www. intechopen.com/books/crude-oil-emulsions-composition-stabilityand-characterization/determination-of-metal-ions-in-crude-oils (Accessed 25 April 2014).

LIU F, GE J, HU X, FEI T, LI Y, JIANG Y, XU Z, DING S, GIESY JP and PAN J (2009) Risk to humans of consuming metals in anchovy (Coilia sp.) from the Yangtze River Delta. Environ. Geochem. Health 31 727-740.

MARTINIAKOVÁ M, OMELKA R, STAWARZ R and FORMCKI G (2012) Accumulation of lead, cadmium, nickel, iron, copper, and zinc in bones of small mammals from polluted areas in Slovakia. Pol. J. Environ. Stud. 21 (1) 153-158.

MASON RP, LAPORTE J-M and ANDRES S (2000) Factors controlling the bioaccumulation of mercury, methylmercury, arsenic, selenium, and cadmium by freshwater invertebrates and fish. Arch. Environ. Contam. Toxicol. 38 283-297.

McGEER JC, BRIX KV, SKEAFF JM, DEFOREST DK, BRIGHAM SI, ADAMS WJ and GREEN A (2003) Inverse relationship between bioconcentration factor and exposure concentration for metals: Implications for hazard assessment of metals in the aquatic environment. Environ. Toxicol. Chem. 22 (5) 1017-1037.

McLEAN JE and BLEDSOE BE (1992) Behaviour of metals in soils. EPA Ground Water Issue, Washington. EPA/540/S-92/018. URL: http://www.epa.gov/superfund/remedytech/tsp/download/issue14. pdf (Accessed 25 April 2014).

NYOGI S and WOOD CM (2003) Effects of chronic waterborne and dietary metal exposures on gill metal-binding: Implications for the biotic ligand model. Hum. Ecol. Risk Assess. 9 (4) 813-846.

OLAFSON RW, SIM RG and BOTO KG (1979) Isolation and chemical characterization of the heavy metal-binding protein metallothionein from marine invertebrates. Comp. Biochem. Physiol. Part C 62 407-416

OTACHI EO, KÖRNER W, AVENANT-OLDEWAGE A, FELLNERFRANK C and JIRSA F (2014) Trace elements in sediments, blue spotted tilapia Oreochromis leucostictus (Trewavas, 1933) and its parasite Contracaecum multipapillatum from Lake Naivasha, Kenya, including a comprehensive health risk analysis. Environ. Sci. Pollut. Res. DOI 10.1007/s11356-014-2602-8.

PALANIAPPAN PL RM and KARTHIKEYAN S (2009) Bioaccumulation and depuration of chromium in the selected organs and whole body tissues of freshwater fish Cirrhinus mrigala individually and in binary solutions with nickel. J. Environ. Sci. 21 229-236.

PAN L and ZHANG H (2006) Metallothionein, antioxidant enzymes and DNA strand breaks as biomarkers of Cd exposure in a marine crab, Charybdis japonica. Comp. Biochem. Physiol. Part C 144 67-75.

PEDLAR RM and KLAVERKAMP JF (2002) Accumulation and distribution of dietary arsenic in lake whitefish (Coregonus clupeaformis). Aquat. Toxicol. 57 153-166.

PEDLAR RM, PTASHYNSKI MD, WAUTIER KG, EVANS RE, BARON CL and KLAVERKAMP JF (2002) The accumulation, distribution and toxicological effects of dietary arsenic exposure in lake whitefish (Coregonus clupeaformis) and lake trout (Salvelinus namaycush). Comp. Biochem. Physiol. Part C 131 73-91.

PHEIFFER W, PIETERS R, VAN DYK JC and SMIT NJ (2014) Metal contamination of sediments and fish from the Vaal River, South Africa. Afr. J. Aquat. Sci. DOI 10.2989/16085914.2013.854732.

QADIR A and MALIK RN (2011) Heavy metals in eight edible fish species from two polluted tributaries (Aik and Palkhu) of the River Chenab, Pakistan. Biol. Trace Elem. Res. DOI 10.1007/ s12011-011-9011-3.
RETIEF N-R, AVENANT-OLDEWAGE A and DU PREEZ HH (2009) Seasonal study on Bothriocephalus as indicator of metal pollution in yellowfish, South Africa. Water SA 35 (3) 315-322.

SEYMORE T, DU PREEZ HH and VAN VUREN JHJ (1995) Manganese, lead and strontium bioaccumulation in the tissues of the yellowfish, Barbus marequensis from the lower Olifants River, Eastern Transvaal. Water SA 12 (2) 159-172.

SKELTON P (2001) Freshwater Fishes of Southern Africa. Struik Publishers, Cape Town.

SQUADRONE S, PREARO M, BRIZIO P, GAVINELLI S, PELLEGRINO M, SCANZIA T, GUARISE S, BENEDETTO A and ABETE MC (2013) Heavy metals distribution in muscle, liver, kidney and gills of European catfish (Silurus glanis) from Italian Rivers. Chemosphere 90 358-365.

STATS SA (2011) Mid-year population estimates. Statistics Release, P0302. Statistics South Africa, Pretoria.

TAKATSU A, KUROIWA T and UCHIUMI A (1999) Arsenic accumulation in organs of the fresh water fish Tribolodon hakonensis. J. Trace Elem. Med. Biol. 13 176-179.

TAN Q-G and WANG W-X (2011) Contrasting patterns of cadmium bioaccumulation in freshwater cladocerans. Limnol. Oceanogr. 56 (1) 257-267.

TESSIER A and CAMPBELL PGC (1987) Partitioning of trace metals in sediments: Relationships with bioavailability. Hydrobiologia 149 43-52.

US EPA (UNITED STATES ENVIRONMENTAL PROTECTION AGENCY) (2011) Exposure Factors Hand Book, 2011 Edition. National Centre for Environmental Assessment, Washington. EPA/600/R-09/052F. URL: http://www.epa.gov/ncea/efh/pdfs/efhcomplete.pdf (Accessed 25 April 2014).

US EPA (UNITED STATES ENVIRONMENTAL PROTECTION AGENCY) (2013a) Mid-Atlantic Risk Assessment. United States Environmental Protection Agency, Washington. URL: http://www. epa.gov/reg3hwmd/risk/human/rb-concentration table/usersguide.htm (Accessed 26 March 2014).

US EPA (2013b) Regional screening level (RSL) fish ingestion table (TR=1E-6, HQ=1). URL: http://www.epa.gov/reg3hwmd/risk/ human/pdf/NOV_2013 FISH_THQ1_watermark.pdf (Accessed on 26 March 2014)

VAN DER OOST R, BEYER J and VERMEULEN NPE (2003) Fish bioaccumulation and biomarkers in environmental risk assessment: a review. Environ. Toxicol. Parmacol. 13 57-149.

VAN VUREN JHJ, DU PREEZ HH and DEACON AR (1994) Effect of pollutants on the physiology of fish in the Olifants River (Eastern Transvaal). WRC Report No. 350/1/94. Water Research Commission, Pretoria.

VISNJIC-JEFTIC Z, JARIC I, JOVANOVIC L, SKORIC S, SMEDEREVAC-LALIC M, NIKCEVIC M and LENHARDT M (2010) Heavy metal and trace element accumulation in muscle, liver and gills of the Pontic shad (Alosa immaculate Bennet 1835) from the Danube River (Serbia). Microchem. J. 95 341-344.

WAGENER A and BOMAN J (2003) Biomonitoring of trace elements in muscle and liver tissue of freshwater fish. Spectrochim. Acta Part B 58 2215-2226.

WEPENER V and VERMEULEN LA (2005) A note on the concentrations and bioavailability of selected metals in sediments of Richards Bay Harbour, South Africa. Water SA 31 (4) 589-596.

WEPENER V, VAN DYK C, BERVOETS L, O'BRIEN G, COVACI A and CLOETE Y (2011) An assessment of the influence of multiple stressors on the Vaal River, South Africa. Phys. Chem. Earth 36 949-962.

YAMAZAKI M, TANIKAZI Y and SHIMOKAWA T (1996) Silver and other trace elements in a freshwater fish, Carasius auratus langsdorfii, from the Asakawa River in Tokyo, Japan. Environ. Pollut. 94 (1) $83-90$

YILMAZ AB (2003) Levels of heavy metals (Fe, Cu, Ni, Cr, Pb, and $\mathrm{Zn}$ ) in tissue of Mugil cephalus and Trachurus mediterraneus from İskenderun Bay, Turkey. Environ. Res. 92 277-281.

ZHOU Q, ZHANG J, FU J, SHI J and GUIBIN J (2008) Biomonitoring: An appealing tool for assessment of metal pollution in the aquatic ecosystem. Anal. Chim. Acta 606 135-150. 
http://dx.doi.org/10.4314/wsa.v40i4.19 Available on website http://www.wrc.org.za

ISSN 0378-4738 (Print) = Water SA Vol. 40 No. 4 October 2014 ISSN 1816-7950 (On-line) = Water SA Vol. 40 No. 4 October 2014 